\title{
Guest editorial for the special issue of selected and extended papers presented at the 10th International Masonry Conference
}

\section{Gabriele Milani ${ }^{1}$}

Received: 8 August 2019 / Accepted: 16 August 2019 / Published online: 2 September 2019 (c) Springer Nature B.V. 2019

\begin{abstract}
This special issue presents a selection of extended and thoroughly revised papers resulting from the 10th (IMC) International Masonry Conference, which took place at the Technical University of Milan (Politecnico di Milano) in Milan, Italy from 9 to 11 July 2019.
\end{abstract}

\section{Preface}

Masonry is one of the oldest materials used in construction engineering and still finds today a wide utilization in building practice. The reason is mainly due to the simplicity of laying stones or bricks on top of each other, either with or without mortar, by means of an almost infinite variation of techniques and a deep intuitive knowledge transmitted basically through rules of thumb from old to new generations, that has been successful ever since remote ages. In the last decades, important developments on materials and applications occurred (think, for instance, of prefabricated wall systems, self-interlocking blocks, seismic resistant infills, sustainable earthen buildings, etc.) but the technique to assemble bricks, blocks and stones remains essentially the same as that used thousand years ago.

In most countries, masonry buildings represent a major part of the architectural heritage which needs to be preserved, especially in all those places where strong earthquakes may occur. Masonry is indeed conceived primarily to withstand vertical loads and its performance under the application of horizontal forces simulating an earthquake proved to be generally quite poor, much more than r.c. and steel structures. As a matter of fact, some recent devastating seismic sequences (e.g. Gorkha Nepal 2015 and Central Italy 2016) have shown once again the insufficient masonry ability to resist strong horizontal accelerations. They have shown also the societal need to develop quickly reliable algorithms/methodologies for the design of safe new masonry buildings and the preservation of existing ones.

In the last decades, the interest on masonry is increased, at least in the most technologically advanced countries, where there is a will to step up research efforts related to conservation and restoration of the built heritage, especially under seismic loads. Huge

Gabriele Milani

gabriele.milani@polimi.it

1 Department of Architecture, Built Environment and Construction Engineering ABC, Technical University of Milan, Piazza Leonardo da Vinci 32, 20133 Milan, Italy 
economic efforts have been made by many national governments for the safeguard of masonry buildings belonging to historical city centers. Recent trends are aimed at a vulnerability reduction by means of non traditional strengthening techniques, which is essentially based on the utilization of Fiber Reinforced Plastics (FRP) and Textile Reinforced Mortars (TRM).

Despite the fact that the scientific research on masonry is nowadays quite advanced and multi-faceted and covers several different specific aspects (such as specific theoreticalnumerical analyses, experimentation, production of new and revision of existing codes, etc.), the issue of the prediction of masonry behavior under seismic loads still remains challenging. The difficulty in studying masonry structures depends on many causes, among the others the most important being its heterogeneous character, the brittle behavior in both tension and compression, the cohesive-frictional response under tangential actions, the geometric complexity of some structural elements such as domes and vaults, etc.

The present Special Issue of Bulletin of Earthquake Engineering includes a selection of eleven extended and thoroughly revised papers originally presented at the 10th International Masonry Conference 10th IMC, which took place 9 to 11 July 2019 at the Technical University of Milan (Politecnico di Milano), Milan, Italy. IMC confirmed in Milan the successful series started more than 30 years ago (1986) in London, where the first International Masonry Conference, organized by the former British Masonry Society (now International Masonry Society, IMS), took place. The conference has now a four-year rhythm and an international character, suffice it to say that the last three editions were organized outside UK: in particular, 8th IMC took place in 2010 in Dresden (Germany), 9th IMC in 2014 in Guimarães (Portugal) and 10th IMC in 2018 in Milan (Italy).

The conference was a co-join event by Technical University of Milan and IMS and it was very successful. Over 150 delegates coming from 30 different countries attended the conference and more than 200 papers were presented. In addition, parallel events for architects and engineering and a student competition with 8 participating teams were organized. The success received confirmed the increasing interest of a diversified scientific and technical community interested on all aspects of masonry research, but in particular on modelling, experimentation, design and conservation.

In this Special Issue, Bartoli et al. (2019) discuss the role played by openings on the first frequency of historical masonry towers. Openings are indeed one of the most important causes of geometric irregularity for a tower, and they may significantly change the period of the structure, therefore playing a role on the seismic response.

Clementi and co-workers (Clementi et al. 2019) perform in their paper several advanced non-linear dynamic analyses by means of a Non-Smooth Contact Dynamics software (LMGC90) in order to assess damages observed in five small masonry churches struck by the Central Italy 2016 seismic sequence.

Longarini et al. (2019) discuss the efficacy of X-Lam roofs in the seismic retrofitting of masonry churches, focusing on a specific case study of a church damaged by a recent Italian strong seismic sequence.

Milosevic et al. (2019) define in their paper fragility curves through nonlinear static analyses for a mixed masonry-RC building stock, whereas Morandi and co-workers (Morandi et al. 2019) address some inconsistencies in the European code -proposing also some improvements-in the application of the seismic design procedures on three modern URM buildings struck by the 2012 Emilia-Romagna seismic sequence.

Savalle et al. (2019) present an experimental and numerical study on a scaled-down dryjoint brick retaining wall, predicting the collapse horizontal acceleration through a pseudostatic approach. 
Senaldi et al. (2019) discuss the final experimental results obtained to evaluate the seismic performance of a half-scale stone masonry building aggregate, whereas Simões et al. (2019) provide a seismic assessment of 19th-20th century URM buildings in Lisbon, evaluating uncertainties and defining fragility curves.

Stockdale et al. (2019) study the seismic capacity of dry-stack masonry arches subjected to hinge control through a multi-mechanism analysis. The base is the recursive utilization of the kinematic theorem of limit analysis.

Türkmen et al. (2019) focus on the in-plane behavior of brick masonry wallettes retrofitted with Fiber Reinforced Cementitious Matrix FRCM and deep mounted carbon strips. The application of FRCM, which is a type of TRM, in combination with deep mounted strips is now considered a retrofitting strategy particularly effective to improve the seismic resistance of shear walls.

Finally, Zucconi et al. (2019) present a validation and an extension of a statistical usability model suitable for unreinforced masonry buildings with different ground motion intensity measures.

I am honored to serve as Guest Editor for this Special Issue of Bulletin of Earthquake Engineering dedicated to the publication of few selected papers presented at the 10th IMC. I would like to thank first of all Prof. A. Ansal, EIC of Bulletin of Earthquake Engineering, who gave me the opportunity to publish this Special Issue and supported me enthusiastically in this difficult but exciting venture. I am sure that the readers will enjoy all the papers belonging to this Special Issue, which undoubtedly collects researches of very high quality on different aspects of earthquake engineering applied to masonry and puts the research forward in such specific topic. I wish also to thank all the authors for their valuable contributions and for the efforts they did in extending and improving the quality of their papers, in order to fit the high standards of the journal. All manuscripts underwent rigorous technical peer review, which helped in increasing further the already high level of the contributions. I therefore also wish to thank all the reviewers for the time they spent in the reviewing phase and for the useful hints they provided.

\section{References}

Bartoli G, Betti M, Marra AM, Monchetti S (2019) On the role played by the openings on the first frequency of historic masonry towers. Bull Earthq Eng. https://doi.org/10.1007/s10518-019-00662-9

Clementi F, Ferrante A, Giordano E, Dubois F, Lenci S (2019) Damage assessment of ancient masonry churches stroked by the Central Italy Earthquakes of 2016 by the non-smooth contact dynamics method. Bull Earthq Eng. https://doi.org/10.1007/s10518-019-00613-4

Longarini N, Crespi P, Scamardo M (2019) Numerical approaches for cross-laminated timber roof structure optimization in seismic retrofitting of a historical masonry church. Bull Earthq Eng. https://doi. org/10.1007/s10518-019-00661-w

Milosevic J, Cattari S, Bento R (2019) Definition of fragility curves through nonlinear static analyses: procedure and application to a mixed masonry-RC building stock. Bull Earthq Eng. https://doi.org/10.1007/ s10518-019-00694-1

Morandi P, Manzini CF, Magenes G (2019) Application of seismic design procedures on three modern URM buildings struck by the 2012 Emilia earthquakes: inconsistencies and improvement proposals in the European codes. Bull Earthq Eng. https://doi.org/10.1007/s10518-019-00650-z

Savalle N, Vincens É, Hans S (2019) Experimental and numerical studies on scaled-down dry-joint retaining walls. Pseudo-static approach to quantify the resistance of a dry-joint brick retaining wall. Bull Earthq Eng. https://doi.org/10.1007/s10518-019-00670-9

Senaldi IE, Guerrini G, Comini P, Graziotti F, Penna A, Beyer K, Magenes G (2019) Experimental seismic performance of a half-scale stone masonry building aggregate. Bull Earthq Eng. https://doi. org/10.1007/s10518-019-00631-2 
Simões AG, Bento R, Lagomarsino S, Cattari S, Lourenço PB (2019) Seismic assessment of nineteenth and twentieth centuries URM buildings in Lisbon: structural features and derivation of fragility curves. Bull Earthq Eng. https://doi.org/10.1007/s10518-019-00618-Z

Stockdale G, Sarhosis V, Milani G (2019) Seismic capacity and multi-mechanism analysis for dry-stack masonry arches subjected to hinge control. Bull Earthq Eng. https://doi.org/10.1007/s10518-01900583-7

Türkmen ÖS, de Vries BT, Wijte SNM, Vermeltfoort AT (2019) In-plane behavior of clay brick masonry wallettes retrofitted with single-sided fabric-reinforced cementitious matrix and deep mounted carbon fibre strips. Bull Earthq Eng. https://doi.org/10.1007/s10518-019-00596-2

Zucconi M, Ferlito R, Sorrentino L (2019) Validation and extension of a statistical usability model for unreinforced masonry buildings with different ground motion intensity measures. Bull Earthq Eng. https:// doi.org/10.1007/s10518-019-00669-2

Publisher's Note Springer Nature remains neutral with regard to jurisdictional claims in published maps and institutional affiliations. 